\title{
マグネトロンスパッタ法により作製したZnS膜の構造と組成
}

正員菅原智明（北海道立工業技術センター）

非会員 福田 永(室蘭工業大学)

非会員 吉野正樹 (北海道職業能力開発短期大学校)
正 員 下野 功（北海道立工業技術センター）

非会員 西野元一 (北海道職業能力開発短期大学校)

非会員 野村 滋 (室菊工業大学)

\section{Structure and Composition of ZnS Films Prepared by Radio-Frequency Magnetron Sputtering}

Tomoaki Sugawara, Member (Hokkaido Industrial Technology Center)

Isao Shimono, Member (Hokkaido Industrial Technology Center)

Hisashi Fukuda, Non-member (Muroran Institute of Technology)

Motokazu Nishino, Non-member (Hokkaido Polytechnic College)

Masaki Yoshino, Non-member (Hokkaido Polytechnic College)

Shigeru Nomura, Non-member (Muroran Institute of Technology)

\begin{abstract}
Zinc Sulfide $(\mathrm{ZnS})$ films are deposited on a quartz-glass substrate using radio-frequency magnetron sputtering. The structure and composition of the films have been investigated by scanning electron microscopy (SEM), X-ray diffraction (XRD) and energy dispersive X-ray spectroscopy (EDX) measurements. The SEM and XRD results indicate that the crystallization of the films is strongly dependent on the sputtering conditions including argon (Ar) gas pressure and target-substrate distance. The pillar structure with preferential (111)-orientation is formed in the films prepared for higher Ar gas pressure during the sputtering. The EDX data indicate the film composition of $\mathrm{Zn}_{\mathrm{X}} \mathrm{S}_{1-\mathrm{x}}$ with zinc concentraton ranging from $X=0.50$ to 0.53 . Photoluminescence spectrum with the peak at $620 \mathrm{~nm}$ is obtained for highly crystallized films. In contrast, non-crystalline films revealed the spectra with peaks at $500,550,620$ and $700 \mathrm{~nm}$. The band gap of $3.27-3.34 \mathrm{eV}$ is observed in the optical absorption spectra of the films prepared all of the sputtering conditions. The highly crystallized $\mathrm{ZnS}$ films with (111)-orientation are obtained only for the sputtering conditions in which the product of Ar gas pressure and target-substrate distance is above 0.8 Torr $\cdot \mathrm{mm}$. The pillar structure could be formed when the impact energy of sputtered particles is decreasing to the surface migration energy.
\end{abstract}

キーワード：ZnS、薄膜、スパッタリング、アルゴンガス圧カ、ターゲット-基板間距離、構造、配向性、組成

\section{1.はじめに}

ZnSは、直接遷移型のワイドギャップ化合物半導体であ ることから、既にブラウン管やエレクトロルミネッセント ランプの蛍光体として実用化されている。近い将来には、 青色LEDや紫外線レーザーなどのオプトエレクトロニクス 関連への応用も期待されている。

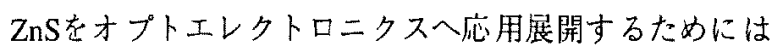
薄膜化技術が必要不可欠である。ZnS薄膜の形成方法には、 スパッタリング法 ${ }^{(1)}$ （5)、分子線エピタキシー法 ${ }^{(5)}$ （ ${ }^{(6)}$ 、

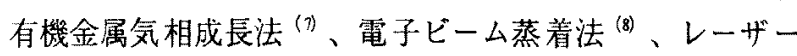

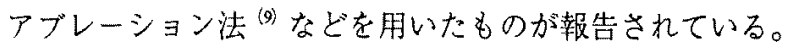

中でもスパッタリング法は、酸化物や硫化物といった高融 点物質の薄膜を比較的低い温度で作製できるという特幑を 有している。現在、スパッタリング法は、保護膜、弾性表 面波フィル夕、透明電極膜などの作製に用いられており、 工業的に重要な淆膜作製プロセスの一つとなっている。 ところで、薄膜形成技術の確立は実用上不可欠であるが、 薄膜形成特有の問題のため、その電気的特性、光学的特性 の制御は十分なされていない。一般に膜の特性は、その構 造に強く依存するので、所望の膜特性を得るためには棈造 の制御が重要となる。さらに、スパッタリング法をより広 範囲に応用展開するには、基板温度を低温化し、熱による 基板や下地勫の特性劣化を防止しなければならない。 
Thornton ${ }^{(10)}$ は、融点 $\mathrm{T}_{\mathrm{m}}$ で規格化された基板温度 $\mathrm{T}_{\mathrm{s}} / \mathrm{T}$ と アルゴン（Ar）ガス圧力をパラメータとした場合、膜構造 は4種類の形態（ZONE-1、ZONE-T、ZONE-2、ZONE-3と称 している）に分類できることを報告している。Motohiroら (11)，(12) はモンテカルロシミュレーション結果から、種々 のターゲット-基板間距離と平均自由行程に依存して、基板 に到達するスバッ夕粒子のエネルギー分布が変化すると考 えている。さらに通常のスパッ夕成膜条件においては、工 ネルギーの高い粒子とエネルギーの低い粒子とが混在して おり、これらが膜質に種々の影響を与えると述べている。 また、神戸ら (13)もモンテカルロ法に基づく計算機シミュ レーションを行った結果、成膜時のArガス圧力を增加させ ると、Ar原子との衝突によって、基板へ入射するスパッ夕 粒子のエネルギーは低くなると報告している。

このような背景加ら、成膜時のArガス圧力およびターゲッ ト-基板間距離をパラメータとして、 $\mathrm{ZnS}$ 膜の特性や構造を 制御することが可能と考えた。また、実際の成膜プロセス においても、スパッタ粒子のエネルギーに注目し、特性や 構造について系統的なデータの収集と解析を行った例はほ とんどない。本研究では、RFマグネトロンスパッタ法を用 い、石英ガラス基板上にZnS膜を作製し、それらの膜の評 価を、X線回折、走査型電子顕微鏡観察、エネルギー分散X 線分光、紫外·可視分光分析、フォトルミネッセンス測定 によって行った。その結果、 $\mathrm{ZnS}$ 膜の構造は、Arガス圧力 が低い場合表面はなめらかで非晶質であるが、Arガス圧力 が高くなるにしたがって、表面に結晶粒が見られるように なった。さらにArガス压力を高く、ターゲットー基板間距離 を長くすると、ZnS膜の配向性は急激に向上し、それに応 じて膜断面には微細な柱状構造が誌められるようになった。 また、 $\mathrm{ZnS}$ 膜の構造および配向性の変化によるバンドギャッ プの違いはほとんど見られないが、フォトルミネッセンス 特性に梳著な差異が認められた。

本報告では、ZnS膜の構造と配向性が、Arガス圧力（P） とターゲット-基板間距雖（D）の積（P・D）をパラメータ として制御可能であることを示した。基板に到達するスパッ 夕粒子のエネルギーを最適化することで、微細な柱状棈造 が形成され、その結果、配向性、結晶性が向上すると考元 られた。

\section{2. 実医方法}

\section{$\langle 2 \cdot 1\rangle \quad$ 試料の作製}

試料は、高周波（RF）マグネトロンスパッ夕装置（日本 真架技術（株）製SH-350C）を用いて作製した。図1にRF マグネトロンスパッタ装置の概略図を示す。ターゲットに は、純度99.99\%のZnSディスク（（株）高純度化学研究所 製ターゲット、4インチ $\mathrm{mm}$ サイズの石英ガラス（（株）金門コルツ製石英板）を 用いた。基板は、前処理としてエタノールで洗浄した後、 スパッタ装置のチャンバー内のステージに乗せた。ステー ジには、100 mm фのAl製の円柱を用いた。スパッ夕成膜

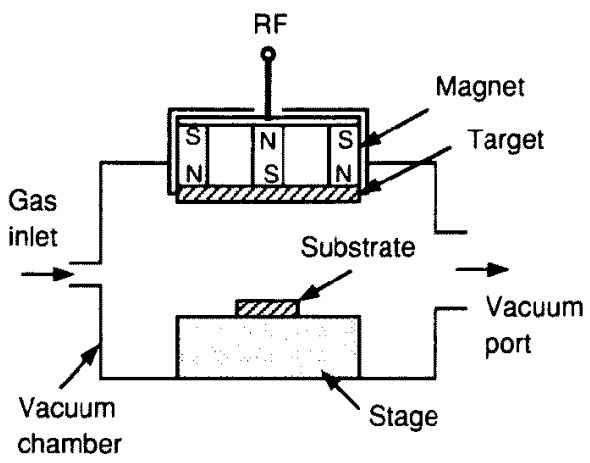

図1 RFマグネトロンスパッタ装置の概略図

Fig.1. Schematic diagram of the RF magnetron sputtering.

の放電ガスには、純度 $99.999 \%$ Arガスを使用した。成膜 手順については、初めにチャンバー内を排気し、圧力が5 $\times 10^{-6}$ Torrになった後、Arガス在チャンバー内に導入し、 Arガス圧力が時間的に変動しないことを確認した。次に、 ターゲットと基板との間にあるシャッターを閉じ、プリス パッ夕を20〜30 min行った。その後、シャッターを開き、 基板上に90〜 220 min成膜を行った。RF電力は25 Wとした。 成膜中の基板温度については、プラズマによる温度上昇の みとした。成膜時のArガス圧力は、1〜16 mTorr、ターゲッ ト-基板間距離は、35〜85 mmとした。

〈2・2〉試料のキャラクタリゼーション

膜厚測定においては、あらかじめカバーガラスで基板表 面の一部を覆い、成膜後にカバーガラスを取り除いて段差 を形成し、この段差を膜厚とした。膜厚は、表面形状測定 器 (日本真空技術 (株) 製Dektak-3030ST) に上り測定し た。

試料の表面観察および断面観察には、走査型電子顕微鏡 （SEM、日本電子 (株) 製JSM-6320F）を用い、加速電圧 $10 \mathrm{kV} 、 2 \times 2.5 \mu \mathrm{m}$ を走査領域とした。

膜の結晶性および配向性は、X線回折装置（XRD、日本 電子（株）製JDX-8020）を用いて評価した。X線管のター ゲットにはCuを用い、管電圧と管電流はそれぞれ $40 \mathrm{kV}$ と $25 \mathrm{~mA}$ とた。測定は1ステップが0.04 degree、計測時間は

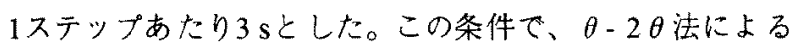
XRDパターンを測定した。

試料の組成分析には、エネルギー分散X線分光分析装置 (EDX、オックスフォード・インストゥルメンツ（株）製

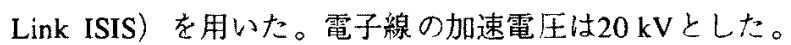
定量計算にはZAF補正法を用いた。但し、膜が薄いために 測定中に石英ガラス基板から発生する酸素（O）の特性X線 も検出されるので、定量計算では○を除いた。

光透過率測定には、紫外・可視分光分析装置 (PERKIN ELMER製Lambda 19）を用いた。膜の透過率は、ダブルビー ム法によって、リファレンスに石英ガラス基板を用いて測 定した。吸収係数は、厚さの異なる試料を用いて、それら の光透過率測定結果から計算した。 
フォトルミネッセンス特性 (PL) は、光源にHe-Cdレー ザー（ライコニタス製）を用い、分光器（（株）二コン製 G500II）、ロックインアンプ、フォトマルを組み合わせて 測定した。測定は試料の温度が $10 \mathrm{~K}$ 、試料入照射するレー

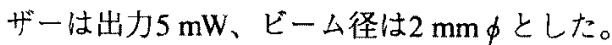

\section{3. 実験結果および検討}

\section{〈3・1〉 ZnS膜の組成分析および構造}

表1にZnS膜の成膜条件と成膜速度およびEDX分析結果を 示す。成膜速度は、Arガス圧力が高いほど、またはターダッ ト-基板間距離が長いほど遅くなる傾向が認められた。得ら れたZnS莫は、Znが50.5〜52.6 at\%、Sが47.4〜49.5 at\%で あった。しかし、EDX分析においては、測定中にSが選択 的に蒸発するため、本来の組成からずれていると考えられ る。実際、分析データの標準偏差 $\sigma$ は0.3〜0.7\%のばらつ きが見られた。したがって、試料および分析精度のばらつ きを考虑すると試料の組成は1：1に近いと考えられる。

基板温度は、成膜中にプラズマからのイオン衝撃や電子

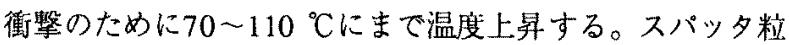
子のエネルギーは5１0 eVであり、Ar原子に衝突してエネ

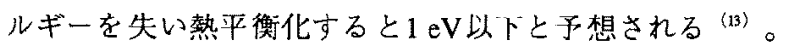
これらの值は基板の熱エネルギーと比較して大きいことか ら、膜成長過程に扔いて基板上をマイグレーションするス パッ夕粒子の工ネルギーは、基板に到達した時のエネルギー に依存し、イオン衝撃や電子衝撃に上る基板温度上昇の影 響は小さいものと考えられる。

種々のArガス生力で作製したZnS莫のXRD測定結果を図2 に示す。ZnSには閃亜鉛鉱棈造とウルツ鉱構造のものがあ り、 $1020^{\circ} \mathrm{C}$ 以下では閃垔鉛鉱棈造が安定であることが知ら れている。また、 $100^{\circ} \mathrm{C}$ 基板温度で作製したZnSスパッタ 膜が閃要鉛鉱構造であるという報告 (1) もある。本実験では、 基板温度が70〜110 $\mathrm{C}$ であことから、主な回折ピークは 閃严鉛鉱構造に起因するものと考えられる。Arガス压力が 1 mTorrでは、回折ピークは非常に小さく、しかもブロード であることから非晶質あるい微結晶な膜と考えられる。 Arがス圧力が高くなるにしたがって (111) ピークが見ら れるようになり、16 mTonで急激に強くなって結晶性の高 い（111）配向膜となった。これまでの報告によると、ス パッタ压力が10 100 mTorrの条件て配向するZnS薄膜が作 製されており (1)、我々の赛験結果と一致している。また (111) 回折線の半洒幅は、Arガス圧力が $16 \mathrm{mTorr}$ では 0.20 degreeであるが、8 mTorrでは0.33 degree、 4 mTorr で は0.40 degreeとArガス圧力の低下とともに広くなることも わかった。16 mTorr以上の圧力については、さらに配向性 の向上が期待されるが、成膜装置のArガス流量と排気速度 とのバランスから奏験不可能であった。

次に、ターゲット-基板間距離を变化させて作製した $\mathrm{ZnS}$ 膜のXRD測定結果を図3に示す。ターダット-基板間距離が $50 \mathrm{~mm}$ 以下では配向性は低いが、50 $\mathrm{mm}$ よも長くすると （111）ピーク強度は大きくなる傾向が見られる。さらに
表1 ZnS膜の成膜条件、成膜速度および組成

Table 1. Deposition conditions, deposition rates, thickness and composition of the $\mathrm{ZnS}$ films.

\begin{tabular}{|c|c|c|c|c|c|c|c|c|c|}
\hline \multicolumn{2}{|c|}{ As Pressure (mTor) } & 1 & 2 & 4 & 8 & \multicolumn{4}{|c|}{16} \\
\hline \multicolumn{2}{|c|}{ T-S Distance $(\mathrm{mm})$} & \multicolumn{5}{|c|}{50} & 35 & 60 & 85 \\
\hline \multicolumn{2}{|c|}{ RF Power (W) } & \multicolumn{8}{|c|}{25} \\
\hline \multicolumn{2}{|c|}{$\begin{array}{c}\text { Deposition Rate } \\
\left(\mathrm{nm} \cdot \min ^{-1}\right)\end{array}$} & 10.9 & 9.5 & 10.0 & 8.8 & 6.6 & 10.6 & 4.9 & 2.7 \\
\hline \multicolumn{2}{|c|}{ Thickness (nm) } & 1090 & 950 & 1000 & 880 & 660 & 950 & 490 & 580 \\
\hline \multirow{2}{*}{$\begin{array}{c}\text { Concentration } \\
\text { (at\%) }\end{array}$} & $\mathrm{Zn}$ & 50.5 & 51.2 & 50.7 & 50.6 & 51.3 & 52.6 & 51.2 & 51.1 \\
\hline & $s$ & 49.5 & 48.8 & 49.3 & 49.4 & 48.7 & 47.4 & 48.8 & 48.9 \\
\hline
\end{tabular}

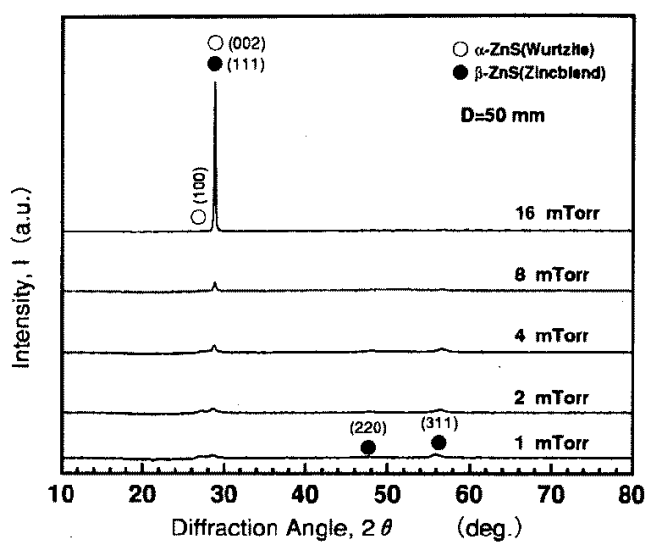

図2 種々のArガス圧力で作製したZnS膜の XRD測定結果

Fig.2. XRD patterns of $\mathrm{ZnS}$ films prepared at various $\mathrm{Ar}$ gas pressure.

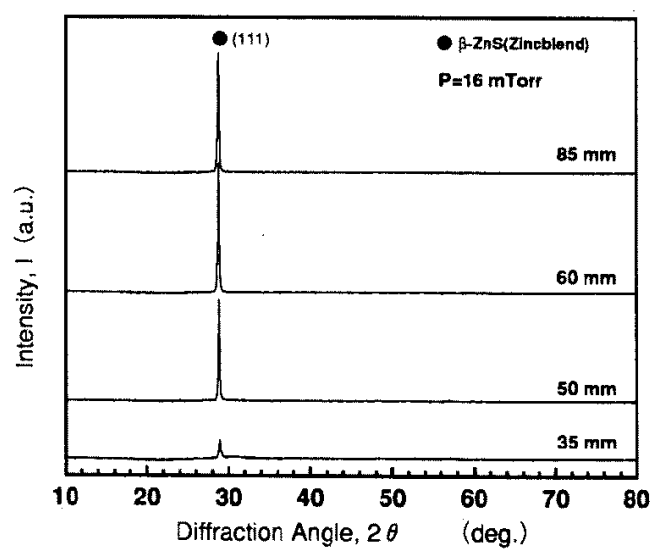

図3種々のターゲット-基板間距離で作製した $\mathrm{ZnS}$ 膜のXRD測定結果

Fig.3. XRD patterns of $\mathrm{ZnS}$ films prepared at various target-substrate distance.

（111）回折線の半価幅は、ターゲット-基板間距離が 35 mmのとき 0.27 degreeであるが、50 mm以上では0.20 degree と狭くなっていることもわかった。このことから (111) ピーク強度の增加は、結晶性の向上によって（111）面間 


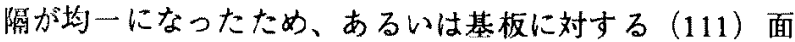
の角度分布がより揃った状態になった結果と考えられる。

Motohiroら (11)（12) は、基板に到達するスパッ夕粒子の エネルギー分布を、ターゲット-基板間距離（D）と平均自 由行程（入）とをパラメーターとして、モンテカルロシミュ レーションによって解析した。その結果、スバッタ粒子が

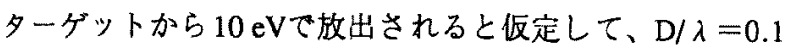
の場合、初期のエネルギーをほとんど失うことはない。し

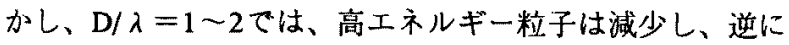
$1 \mathrm{eV}$ 以下の低エネルギー粒子が增える。さらに、D/ $\lambda=5$ 一10となると、ほとんどが1 eV以下の熱平衡化した低工ネ ルギー粒子に変化すると報告している。

実際のスパッタリング法による薄膜作製では入を直接的 なパラメーターとすることは困難であるため、本報告では $\operatorname{Ar} ゙$ ス压力 (P) を平均自由行程の代りのパラメーターと した。また $\lambda(\mathrm{mm})$ はP (Torr) に反比例し、 $\lambda \fallingdotseq 10^{-1} / \mathrm{P}$ であることが知られている(14)。したがって、P·D

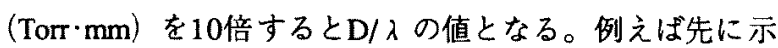
した、D/ $\lambda=0.1$ はP. $\mathrm{D}=0.01$ Torr $\cdot \mathrm{mm}$ に対応する。つまり $\mathrm{P} \cdot \mathrm{D}$ の変化は、基板に到達する高エネルギー粒子と低エネ ルギー粒子との割合を変化させることを意味し、P·Dが大 きいほど、低エネルギー粒子の割合は多くなると考えられ る。したがって、このP·Dをパラメータとしてスパッタ粒 子のエネルギ一を変化させ、ZnS膜の配向性や特性を部価 することで、スパッタ粒子のエネルギーの効果を明らかに することができる。さらに、Motohiroら (12) はスパッ夕粒 子が基板に到達する割合をモンテカルロ法で求めているが、 この傾向は表1に示す成膜速度のP·D依存性とほほ一致する。 本実験においては基板温度が $100^{\circ} \mathrm{C}$ 前後であったため、成 膜速度が単位時間に基板に到達するスパッ夕粒子の個数に 比例したとすると、成膜速度はP・Dを用いて説明できる。 このことからもP·Dは有効なパラメータと考えられる。

$\mathrm{ZnS}$ 膜の配向性の評価は、X線回折で得られた（111）ピ一 ク強度をもとにして行った。膜が薄い場合、入射X線はほ とんど減衰せずに膜／基板界面まで達する。このとき生じ る回折ピークの強度は、試料へのX線の照射面積が同じで

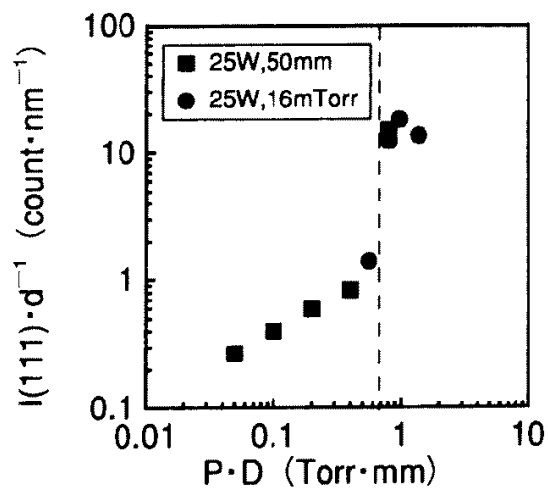

図4 $\mathrm{ZnS}$ 膜の（111）配向のP·D依存性

Fig.4. The dependence of parameter, $P \cdot D$ on the (111)-orientation.
あれば膜厚に比例すると考えられる。ZnS膜では、厚さが $100 \sim 1500 \mathrm{~nm}$ 程度の場合 (111) ピーク強度は膜厚に比例 するため、(111) ピーク強度を膜厚で割った值によって 配向性の評価が行われている(1)（2)。図4に、ZnS膜の

（111）配向のP.D依存性を示す。この図加ら（111）配向 は、P·Dが大きくなるにしたがって徐々に増加し、臨界值 を越えると急激に上年することがわかる。このときの臨界 值は0.8 Torr·mmであった。前述したように、スパッ夕成膜 中の気体原子の平均自由行程は、1 Torr のときおよそ10-1 $\mathrm{mm}$ であことが知られており、これから $\mathrm{D} / \lambda$ を計算する

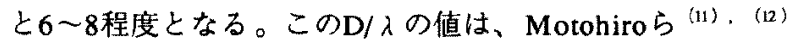
によるシミュレーション結果によると、ターゲットから放 出されたスパッ夕粒子が気体原子に衝突し、エネルギーを 失い、熱平衡化する領域である。これらのことから、基板 に到達するスパッタ粒子を熱平衡化させることによって、 石英ガラス基板上に（111）配向するZnS膜が作製できるこ とがわかった。

\section{〈3.2〉膜の微細構造とその要因}

図5に、ターゲット-基板間距離を $50 \mathrm{~mm}$ 、パラメータを スパッタ成膜時のArガス圧力として作製した、ZnS膜の表 面のSEM像を示す。Arガス圧力が2 mTorrの場合、コントラ ストがほとんど見られない。これは、膜の表面の凹凸が小 さいためと考えられる。また、Arガス圧力を 2 mTorr以下に すると、ZnS膜の表面の凹凹がさらに減少し、結晶粒も不 明暸になった。一方、Arガス圧力を 4 mTorrと高くすると、 結晶粒が認められるようになり、8 mTorrにおいては、結晶 粒はより明確となる。このときの結晶粒サイズは100 nm程 度であった。さらにArガス圧力を 16 mTorrに上げると、前 述した $100 \mathrm{~nm}$ 程度の結晶粒の間に、微細な結晶粒が観察さ れる。SEM観察から、この微細組織は10 nm前後のサイズ の結晶粒で構成されていることがわかった。

図6に、Arガス圧力を 16 mTorr、ターゲット-基板間距離 をパラメータとして作製したZnS膜の表面のSEM像を示す。 ターゲットー基板間距離が50 mmでは、前述したように大き な結晶粒の間に微細な結晶粒が観察される。ターゲット-基 板間距離を $50 \mathrm{~mm}$ ら長くすると、大きな結晶粒は消え、 微細な結晶粒で埋め尽くされるようになる。さらに、ター ゲット-基板間距離を $60 \mathrm{~mm}$ 以上にしても、表面観察結果に 大きな違いはなかった。逆にターゲットー基板間距離を短く すると、膜表面の微細組織は消失し、大きな結晶粒のみと なる。ターダット-基板間距離が長くなるにしたがって結晶 粒サイズは小さくなるが、図3に示す回折線の半価幅が狭 くなっていることから、結晶性は向上しているものと考え られる。また、ターゲット-基板間距離が $35 \mathrm{~mm}$ における結 晶粒の大きさや形状は、図5に示すArガス圧力が8 mTorrの ものと酷似している。これは、ターゲット-基板間距離を短 くすることが、Arガス压力を低くすることと同様な効果が あるためと考えられる。前述のXRD測定結果とこれらの SEM像から、P·Dの違いによって微細構造が変化している ことが明らかとなった。 


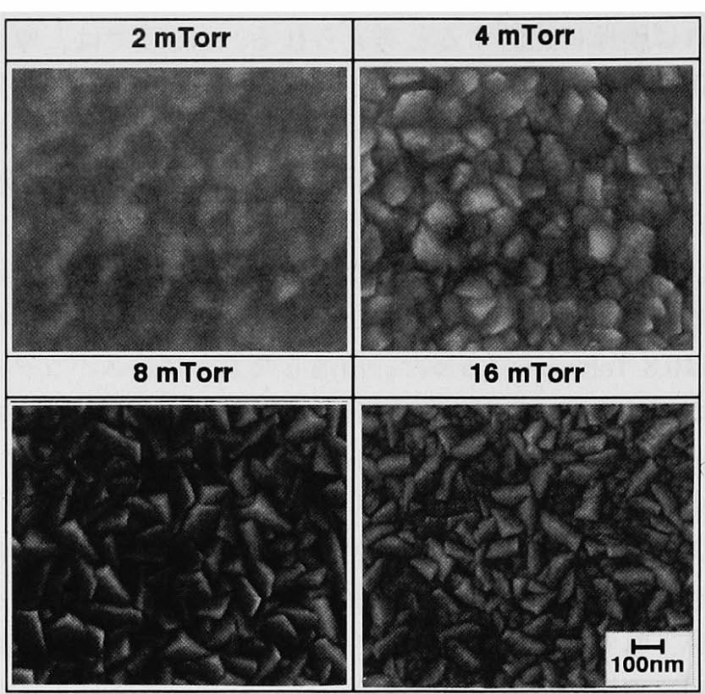

図5種々のArガス圧力で作製したZnS膜表面の SEM像 $D=50 \mathrm{~mm}$

Fig.5. The surface SEM images of $\mathrm{ZnS}$ films prepared at various $\mathrm{Ar}$ gas pressure. $\mathrm{D}=50 \mathrm{~mm}$.

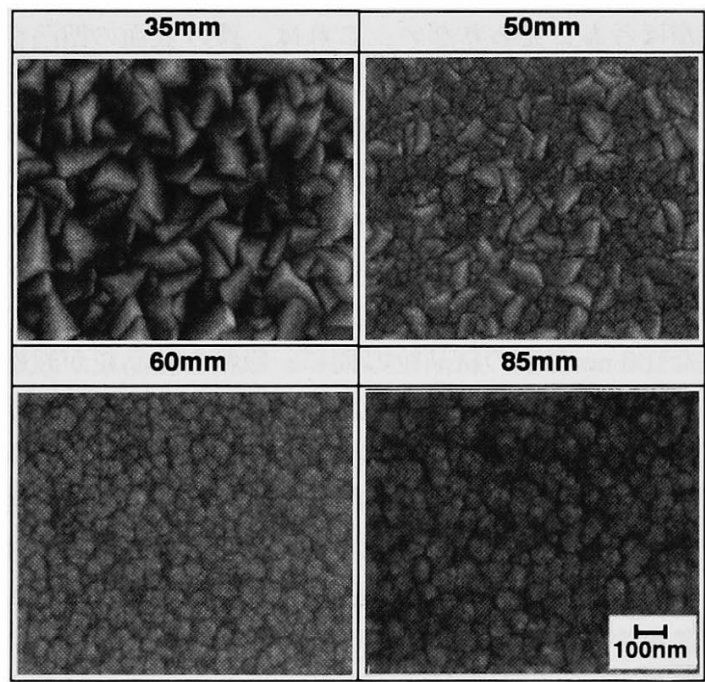

図6 種々のターゲット-基板間距離で作製した $\mathrm{ZnS}$ 膜表面のSEM像 $\mathrm{P}=16 \mathrm{mT}$ Torr

Fig.6. The surface SEM images of ZnS films prepared at various target-substrate distance. $\mathrm{P}=16$ mTorr.

次に、膜成長の様子を調べるため、試料を45 degree傾け て膜断面の観察を行った。図7に、ZnS膜断面のSEM像を示 す。 $\mathrm{P} \cdot \mathrm{D}=0.1 \mathrm{Torr} \cdot \mathrm{mm}(\mathrm{P}=2 \mathrm{mTorr}, \mathrm{D}=50 \mathrm{~mm})$ と小さ いときには、断面はなめらかで柱状構造も見られないが、 $\mathrm{P} \cdot \mathrm{D}=0.4$ Torr $\cdot \mathrm{mm}(\mathrm{P}=8 \mathrm{mTorr}, \mathrm{D}=50 \mathrm{~mm})$ と大きくな ると柱状構造が認められる。さらにP·Dを大きくすると、 一部に微細な柱状構造も現れ、 $\mathrm{P} \cdot \mathrm{D}=1.0 \mathrm{Torr} \cdot \mathrm{mm}(\mathrm{P}=16$ $\mathrm{mTorr}, \mathrm{D}=60 \mathrm{~mm}$ ) では全て微細な柱状構造となることが

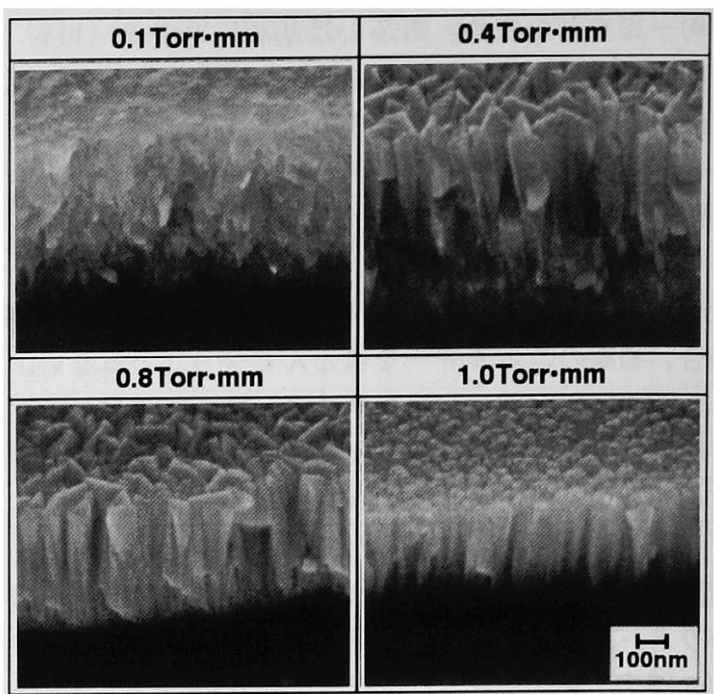

図7種々のP·D条件で作製した ZnS膜断面の SEM像

Fig.7. The cross-sectional SEM images of $\mathrm{ZnS}$ films prepared at various P.D conditions.

わかる。また、P·Dが1.0 Torr·mmでは全体が柱状構造となっ ているが、P·D $=0.4$ Torr $\cdot \mathrm{mm}$ では、基板近傍で一度微細な 組織が形成した後、柱状構造が表面方向に現れている。さ らに、その結晶粒のサイズは表面に近づくほど大きくなっ ていることもわかった。

Thornton ${ }^{(10)}$ の構造モデルによると、基板温度が低い場 合、Arガス圧力が高いときはZONE-1の微小柱状でカラム間 に空隙や孔が存在する欠陥膜となり、またArガス圧力が低 いときはZONE-Tの緻密な繊維状の柱状構造となる。しかし 本研究の $\mathrm{ZnS}$ 膜の場合は、比較的 $\mathrm{Ar}$ ガス圧力が高い 16 mTorrでZONE-Tの緻密な緎維状の柱状構造が形成されるこ とが明らかとなった。シミュレーションによる神戸ら (13) の報告と考え合わせると、柱状構造が形成した要因として、 Arガス圧力が高いとスパッタ粒子は適度に散乱され、基板 への入射方向がランダムになったこととスパッタ粒子のエ ネルギーが低くなったことが考えられる。一方、Arガス圧 力が低いときには、高エネルギーのスパッタ粒子が基板に ほほ垂直に入射するため、基板の表面へ向かう結晶成長が 阻害され、柱状構造が形成されなかったものと考えられる。

以上のことから $\mathrm{ZnS}$ 膜形成において、基板へ到達するス パッタ粒子のエネルギーを低くすることで、基板上でのス パッ夕粒子の移動や拡散が十分なされ、高配向膜が成長し たと考えられる。さらに、スパッ夕粒子が基板に到達する 途中でAr原子に散乱され、斜影効果が生じたために微細な 柱状構造が形成し ${ }^{(13)}$ ，(14)、その結果、高配向膜が得られ たものと考えられる。また、図7のP·D=0.4 Torr · mmに見 られるように、高エネルギー粒子には結晶粒同士を合体さ せ、面内方向の成長を促進させる能力もあると考えられ、 これら低エネルギー粒子と高エネルギー粒子の割合を変化 させることによっても、所望の構造のZnS膜が作製可能で 
あることが明らかとなった。

\section{〈3.3〉膜の吸収スペクトルとPL特性}

$\mathrm{ZnS}$ 膜の光透過率を測定し、膜厚の異なる試料の光透過 率によって吸收係数 $\alpha$ を計算した。二つの試料の膜厚を $\mathrm{d}$ 、 $\mathrm{d}_{2}$ そそれぞれの光透過率を $\mathrm{I}_{\mathrm{T}} 、 \mathrm{I}_{\mathrm{T} 2}$ とすると、表面反射の影 翌を消去した式が得られ、これより吸収係数 $\alpha$ は、 $\alpha=$ $\left(\mathrm{d}_{1}-\mathrm{d}_{2}\right)^{-1} \cdot \ln \left(\mathrm{I}_{\mathrm{T} 2} / \mathrm{I}_{\mathrm{T}}\right)$ と表される。また、ZnSは直接遷 移型であるため、その吸収係数の 2 乗が光子のエネルギー に比例することが知られている。図8に、基礎吸收端付近 の吸収スペクトルを示す。各スベクトルの直線部分の外挿 から求められる光学的バンドギャップは、 $3.27 \sim 3.34 \mathrm{eVで}$ あり、作製条件、膜構造が異なっても光学的バンドギャッ プにははとんど違いが認められなかった。また高配向膜の 光学的バンドギャップは3.32 eVとなり、この值はKimijima ら ${ }^{(15)} に よ る \mathrm{ZnS}$ スパッ夕膜の光学的バンドギャップの值と ほ泟一致していた。それぞれの吸収スペクトルには裙が見 られることから、膜中には欠陥が生じているものと考元ら れる。欠陷は禁止帯中に準位を形成し、そのことが、本実 験の光学的バンドギャッブがバルクのバンドギャップ3.7 $\mathrm{eV}$ より小さくなった原因の一つと考えられる。

結晶性の異なる試料のPLスペクトルを図9に示す。図中 の（a） はP $\cdot \mathrm{D}=1.0$ Torr $\cdot \mathrm{mm}(\mathrm{P}=16 \mathrm{mTorr}, \mathrm{D}=60 \mathrm{~mm})$ で作製した（111）配向膜、（b）は $\mathrm{P} \cdot \mathrm{D}=0.05 \mathrm{Torr} \cdot \mathrm{mm}$ ( $\mathrm{P}=1 \mathrm{mTorr}, \mathrm{D}=50 \mathrm{~mm})$ で作製した配向性の低い膜で ある。なお、（b）の試料はPL強度が弱いため、感度を5 倍 に上げている。高配向性の（a）の膜では約 $620 \mathrm{~nm}$ の波長 にピークをもった、500〜800 nmにわたる幅の広いスペク トルが観測される。一方、（b）の配向性の低い膜につい ては、スペクトルの最大ピーク波長が（a）と同じく約 620 nmであるが、この他に500、550、700 nmの波長にサブピー クが見られる。さらに、スペクトル全体は、500〜900 nm

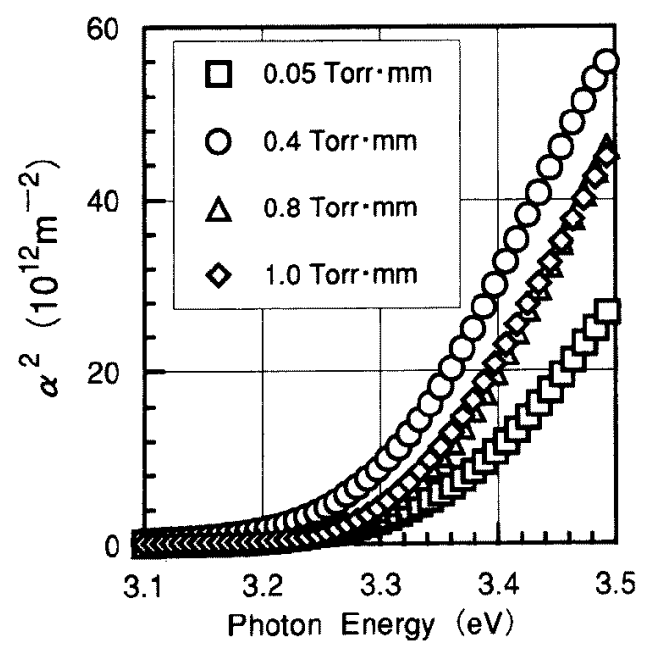

図8 ZnS膜の基礎吸収端波長付近の 吸収スペクトル

Fig.8. The absorption edge spectra of the $\mathrm{ZnS}$ films.
に広がっている。したがって、どちらの膜についても、PL スペクトルは幅の広いものとなることから、膜中には欠陷 が存在し、その久陥が样々な準位を形成しているものと考 えられる。この欠陷としては、ZnあるいはSの空孔や膜に 取り込まれたArによるものが考えられる。しかし、このAr は微量なために蛍光線分析では検出不可能であった。ま た、ZnS膜のPLスペクトルの報告例も少ないことから、ピー クの起源を解明することはできなかった。結晶性の良い（a） の試料ではピーク分離が見られない理由として、一つはサ プピークを形成する染位が減ったこと、もう一つはメイン のピークが強くなったためにサブピークは見えなくなった ことが考えられる。一般にスパッタ粒子のエネルギーが大

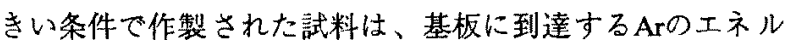
ギーが高いため、Arは膜の内部にまで達し、結果として膜 のAr濃度は高くなる。一方、スパッ夕粒子のエネルギーが 小さい条件で作製された膜のA濃度は低くなると考えられ る。したがって（a）と（b）のスペクトルが異なる原因と して、膜のA禯度の違いによるもの、さらに成膜条件によっ て膜へ入射するArやスパッ夕粒子のエネルギーが異なるた めに、生じる欠陥の種類が変わったことが考えられる。ま た配向性、結晶性の低い膜のPL強度が弱かった原因として、 成膜中に基板へ到達するスパッタ粒子のエネルギーが大き く、膜に強いダメージが与えられたため、非発光堙移を生 じさる欠楩が多かったことが考えられる。

本論文では主にスパッタ粒子のエネルギーに注日してい るが、基板へ入射するArイオンあるいは膜に取り込まれた Arなども薄膜の構造や特性に影響するものと思われる。こ の点は今後の研究課題であり、スパッタリング法をより広 範囲に応用するためには重要な問題と考えている。

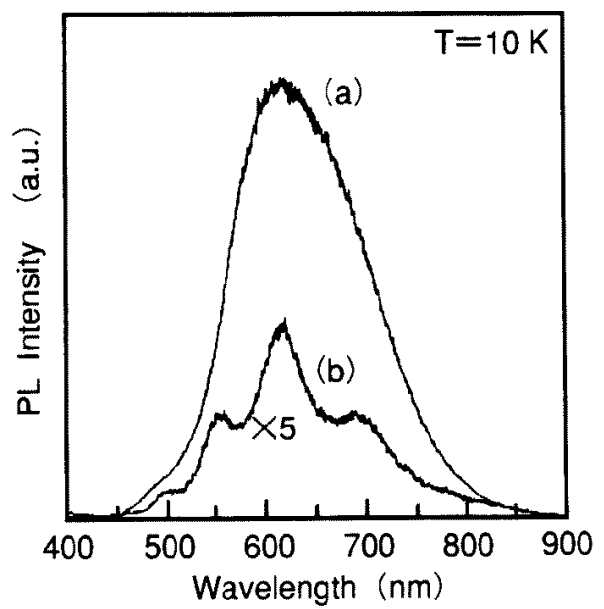

図9 結晶性の異なる $\mathrm{ZnS}$ 膜のPLスペクトル

(a) (111) 配向膜 $(P \cdot D=1.0 \mathrm{Torr} \cdot \mathrm{mm})$,

(b) 低配向膜 $(\mathrm{P} \cdot \mathrm{D}=0.05 \mathrm{Torr} \cdot \mathrm{mm})$

Fig.9. The PL spectra of the ZnS films with different crystallization.

(a) (111)-orientation $\mathrm{ZnS}$ film ( $\mathrm{P} \cdot \mathrm{D}=1.0 \mathrm{Torr} \cdot \mathrm{mm})$,

(b) non-crystallne $\mathrm{ZnS}$ film $(\mathrm{P} \cdot \mathrm{D}=0.05 \mathrm{Torr} \cdot \mathrm{mm})$ 


\section{4.まとめ}

RFマグネトロンスパッタ法を用い、成膜時のArガス在 力、ターゲット-基板間距離をパラメータとして、石英ガラ ス基板上にZnS膜を作製した。実験結果を以下にまとめる。 （1）Arガス圧力が高くなるにしたがって、（111）配向

性が向上し、微細な柱状構造のZnS膜となった。

（2）ターゲット-基板間距離を長くすると、（111）配向 性が増加し、微細な柱状構造のZnS膜となった。

（3）Arガス圧力（P）とターゲット-基板間距離（D）の積 (P·D）の増加にともない（111）配向性が向上し、臨 界值（0.8 Torr· mm）を越えると急激に上昇した。

(4) 膜組成はZn濃度がX $=0.50 \sim 0.53 の \mathrm{Zn}_{x} \mathrm{~S}_{1-\mathrm{x}}$ であった。

(5) 光学的バンドギャップは、膜構造、配向性、結晶性 が巽なってもほとんど違いが見られなかった。一方、PL 特性は結晶性によって異なることがわかった。 本研究では、ZnS膜の構造と配向性は、Arガス圧力 (P) とターダット-基板間距離（D）の積（P·D）をパラメータ として制御できることを示した。また、（111）配向した 結晶性 $\mathrm{ZnS}$ 膜は、0.8 Torr· $\mathrm{mm}$ 以上のスバッ夕条件において 得られることがわかっったこのことから、スバッタ粒子の 衝突エネルギーが、表面マイダレーションエネルギーまで 低下することで柱状の構造が形成されると考えられる。

(平成11年6月16日受付，平成11年12月15日再受付)

\section{文 献}

(1) H.Xian, P.Benalloul, C.Barthou and J.Benoit : "Quantitative Analyses and Crystallographic Studies of ZnS:Mn Thin Films Prepared by R.F. Magnetron Reactive Sputtering", Thin Solid Films, Vol.248, No.2, p.193 198 (1994)

(2) J.M.Blackmore and A.G.Cullis : "The Structure of $\mathrm{ZnS}$ Thin Films Deposited by R.F. Sputtering, Thin Solid Films", Vol.199, No.2, p.321 334 (1991)

(3) C.W.Wang, J.Y.Liao, Y.-K.Su and M.Yokoyama : "The Relation between Luminous Properties and Oxygen Content in ZnS:TbOF Thin-film Electroluminescent Devices Fabricated by Radio-frequency Magnetron Sputtering Method", IEEE Trns. Electron Devices, Vol.45, No.4, p. $757 \sim 762$ (1998)

(4) Y.Kawakami, T.Taguchi and A.Hiraki : "Characterization of Epitaxal ZnS Films Fabricated by Sputtering in Controlled $\mathrm{H}_{2} \mathrm{~S}$ Vapor", Surface Science, Vol.168, No.1/3, p.571 576 (1986)

(5) I.P.McClean, D.M.Spink, C.B.Thomas and K.Tsakonas : "Low Temperature Epitaxial Deposition of $\mathrm{ZnS}$ onto (100)Si by R.F. Magnetron Sputtering and Molecular Beam Epitaxy", J.Crystal Growth, Vol.143, No.3/4, p.172 175 (1994)
(6) M.Yokoyama, K.Kashiro and S.Ohta : "Molecular Beam Epitaxial Growth of $\mathrm{ZnS}$ on a (100)-Oriented Si Substrate", J.Crystal Growth, Vol.81, No.1/4, p.73 78 (1987)

(7) C.W.Wang, T.J.Sheu, Y.K.Su and M.Yokoyama : "The Study of Aging Mechanism in ZnS:Mn Thin-Film Electroluminescent Devices Grown by MOCVD", Appl. Surface Science, Vol.113/114, p.709 713 (1997)

(8) Z.K.Kun, D.Leksell, P.R.Malmberg, J.Murphy and L.J.Sienkiewicz: "The Influence of Chlorine of the Crystal Structure and Electroluminescent Behavior of ZnS:Mn Films in Thin Film Electroluminescent Devices", J.Electronic Materials, Vol.10, No.1, p.287 300 (1981)

(9) J.W.McCamy, Douglas H.Lowndes, J.D.Budai, R.A.Zuhr and Xiao Zhang : "Epitaxial ZnS Films Grown on GaAs (001) and (111) by Pulsed-Laser Ablation", J.Appl.Phys., Vol.73, No.11, p.7818 7822 (1993)

(10) J.A.Thornton : J.Vac.Sci.Technol. , Vol.11, p.666 (1974)

(11) T.Motohiro and Y.Taga : "Monte Carlo Simulation of Thermalization Process of Sputtered Particles" , Surface Science, Vol.134, No.1, p.L494 L499 (1983)

(12) T.Motohiro and Y.Taga: "Monte Carlo Simulation of the Particle Transport Process in Sputter Deposition", Thin Solid Films, Vol.112, No.2, p.161 173 (1984)

（13）神戸明宏、星 陽一、鈴木英佐: 「対向ターゲット式ス パッタ法により得られる薄膜の微細構造の計算機シミュ レーション」, 東京工芸大学工学部紀要, Vol.19, No.1, p.72 77 (1997)

（14）金原 粲：「スパタリング現象」，東京大学出版会， p. $180 \sim 181$ (1991)

(15) H.Kimijima, M.Kitagawa, R.Inoue, N.Shiraishi, M.Hoashi, K.Ichino and H.Kobayashi : "Deposition and Characterization of $\mathrm{Zn}_{x} \mathrm{Mg}_{1-x} \mathrm{~S}$ Thin Films on Amorphous Substrates", Appl. Surface Science, Vol.113/114, p.432 〜 435 (1997) 


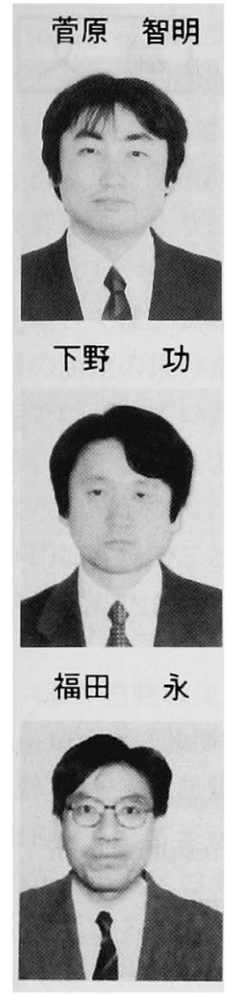

（正員）1965年2月24日生まれ。90年3月 岩手大学大学院工学研究科電気工学専攻 修士課程修了。現在北海道立工業技術セ ンター勤務。主として薄膜電子材料の研 究開発に従事。

（正員）1959年10月3日生まれ。84年3月 室蘭工業大学大学院工学研究科金属工学 専攻修士課程修了。現在北海道立工業技 術センター勤務。主として酸化物系半導 体、酸化物系高温超伝導体の研究開発に 従事。工博。

（非会員）1956年3月23日生まれ。81年東 京都立大学大学院理学研究科修士課程修 了、84年同大学院博士課程単位取得満期 退学。同年沖電気工業 (株) 入社。微細 CMOSおよびフラッシュメモリの開発に 従事。94年室蘭工業大学工学部電気電子 工学科助教授。知能化センサ、次世代半 導体デバイスに関する研究に従事。工博 (早稲田大学) 。電子情報通信学会、応 用物理学会会員。

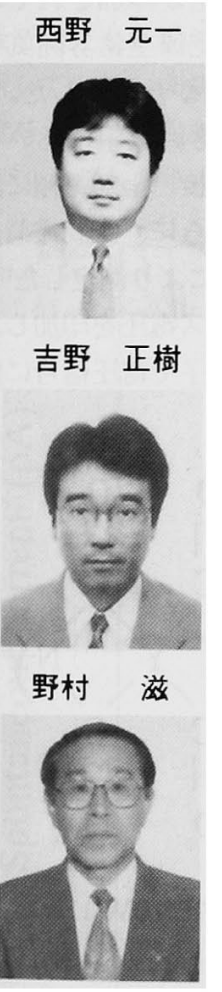

(非会員) 1963年1月1日生まれ。87年長 岡技術科学大学大学院工学研究科電子機 器工学専攻修士課程修了。現在北海道職 業能力開発短期大学校情報技術科講師。 主にECRプラズマCVD法を用いたZnSe系 薄膜の低温成長に関する研究に従事。電 子情報通信学会、応用物理学会会員。 (非会員) 1961年10月18日生まれ。85年 3 月室蘭工業大学工学部第 II 部電気工学科 卒業。同大電子工学科技官を経て、90年 北海道職業能力開発短期大学校電子技術 科講師。薄膜電子材料の表面分析、プラ ズマCVDによるSiC薄膜堆積の研究に従事。 電子情報通信学会、応用物理学会会員。 （非会員）1937年6月17日生まれ。66年東 北大学大学院工学研究科博士課程修了。 同年室蘭工業大学工学部電気工学科講師、 68年同電子工学科助教授、84年同教授、 90 年同電気電子工学科教授。シリコン極 薄陽極酸化膜の形成、高効率太陽電池、 次世代半導体デバイスに関する研究に従 事。工博。電子情報通信学会、応用物理 学会会員。 